(c) American Dairy Science Association, 2006.

\title{
Fertility Responses of Mexican Holstein Cows to US Sire Selection
}

\author{
E. G. Cienfuegos-Rivas, ${ }^{\star 1}$ R. W. Blake,† P. A. Oltenacu, $\dagger$ and H. Castillo-Juarezł \\ *Universidad Autónoma de Tamaulipas, Cd. Victoria Tamaulipas, México 87030 \\ †Department of Animal Science, Cornell University, Ithaca NY 14853 \\ ¥Universidad Autónoma Metropolitana-Xochimilco Calzada del Hueso 1100, DF, México 04960
}

\begin{abstract}
Genetic relationships between 2 fertility traits and milk production were investigated using mature-equivalent lactation records of 55,162 daughters of 1,339 Holstein sires in Mexico and 499,401 daughters of 663 Holstein sires in the northeastern United States. Data sets contained yields in first and second lactation, age at first calving (AFC), and calving interval (CI). There were 474 US sires in common between countries. A herd-year standard deviation criterion defined nonoverlapping low- $(\leq 1,300 \mathrm{~kg})$ and high- $(\geq 1,600 \mathrm{~kg})$ opportunity Mexican herd environments and a low-opportunity $(\leq 1,024 \mathrm{~kg})$ US environment. Genetic variances for the average Mexican herd (all data) for AFC and CI were 65 and $85 \%$ as large as those obtained from half-sisters in the average US herd. Genetic correlations for firstlactation milk in the average US herd and AFC and CI in the average Mexican environment were unfavorable (0.18 and 0.10). Regression coefficients of AFC in Mexican environments on US genetic gain in milk ranged from 2 to $7 \mathrm{~d} / 1,000 \mathrm{~kg}$. However, the favorable predicted response in AFC from genetic gain in milk in Mexican environments, like those in average US herds, ranged from -4 to $-7 \mathrm{~d} / 1,000 \mathrm{~kg}\left(\mathrm{r}_{\mathrm{g}}=-0.20\right)$. This unequal $\mathrm{AFC}$ response may indicate genotype by environment interaction in fitness performance or differential breeding management of high and low yielding Mexican cows. The potential effects of age at first service of breeding females need to be disentangled to accurately assess genetic improvement needs for Mexican Holstein herds. Key words: genotype by environment interaction, milk yield, age at first calving, Mexico
\end{abstract}

\section{INTRODUCTION}

Mexico has imported Holstein germplasm especially from the United States and Canada since 1950, primarily because daughters of US sires produce more milk than daughters of sires of other origin (Powell and Dick-

Received March 15, 2005.

Accepted February 1, 2006.

${ }^{1}$ Corresponding author: ecienfue@uat.edu.mx inson, 1977; Blake et al., 1988; Powell and Wiggans, 1991; Stanton et al., 1991a,b; Cienfuegos-Rivas et al., 1999). The effect of this decision on reproductive performance also needs evaluation because of the important unfavorable relationship between fertility and milk production (Hansen et al., 1983; Bonczek et al., 1992; Bagnato and Oltenacu, 1993; Nebel and McGilliard, 1993; Marti and Funk, 1994). After low milk yield and mastitis, unsatisfactory reproduction accounts for about onethird of cow disposals from Mexican herds (Cabello and Ruiz, 1998). In the short term, greater milk sales partially compensate for modest costs of associated health disorders and reduced reproductive performance. However, the accumulation of replacement costs from this genetic trend could curtail net economic returns (Pösö and Mäntysaari, 1996).

Although certain attention has been devoted to genotype by environment interaction in milk yield, unequal genetic relationships between milk and fertility traits across environments also have been suggested (Castillo-Juarez et al., 2000; Windig et al., 2005). Given the disturbance in genetic expression of milk production between herd opportunity groups in the US and Colombia (Stanton et al., 1991a,b), Brazil (Costa et al., 2000), Mediterranean Italy (Raffrenato et al., 2003), and Mexico (Stanton et al., 1991b; Cienfuegos-Rivas et al., 1999), heterogeneous genetic (co)variances should be expected in other traits. For example, genetic expression of age at first calving of Holstein cows (a composite of fertility and physical maturity) differed between Brazilian and Colombian herd environments (Cerón-Muñoz et al., 2004). Consequently, the main objective of this study was to evaluate the impact of US Holstein sires on the fertility performance of their Mexican daughters. To accomplish this, genetic parameters were estimated to determine the influence of US sires on age at first calving and first calving interval in Mexican herds.

\section{MATERIALS AND METHODS}

\section{Data and Edits}

Data were obtained from the Mexican Holstein Association (Queretaro, Mexico) and from the USDA Animal Improvement Programs Laboratory (Beltsville, MD). 
Mexican data comprised 87,920 first-calving records of 305-d mature equivalent milk yield from Holstein cows calving from 1971 to 1995 . These cows were Mexicanborn daughters of US (64\%), Canadian (14.4\%), and Mexican sires $(21.6 \%)$. The final data consisted of 56,162 Mexican first-calving records from daughters of 1,339 sires in 164 herds. The US data comprised 976,477 first-calving records of 305-d milk yields from Holstein cows calving from 1980 to 1993 in the northeastern United States. The US data were restricted to the northeastern region to reduce sample size and because most of the common sires were utilized in this region. The final US data comprised 499,401 first-calving records from daughters of 663 US and Canadian sires in 3,685 herds. Sires were required to have at least 3 daughters in at least 2 herds, and each herd was required to provide at least 5 records. There were 474 US and Canadian sires with daughters in Mexico $(32,860$ records) and in the United States $(408,894$ records). Age at first calving (AFC) and calving interval (CI) were calculated from dates of birth and first and second calving.

Herd opportunity environments were defined by herd-year phenotypic standard deviation (HYSD) for first-lactation milk yield. As previously indicated, this criterion has been utilized to study differential responses in milk yield and in fertility (Castillo-Juarez et al., 2000; Cerón-Muñoz et al., 2004). The key assumption is that herds with greater expressed variation utilize more management inputs to provide greater opportunity for cows to express more fully their genetic potentials (Raffrenato et al., 2003). Consequently, 2 nonoverlapping opportunity classes were defined for Mexico (HYSD $<1,300 \mathrm{~kg}$ and HYSD $>1,600 \mathrm{~kg}$ ) and a low opportunity class was defined for the United States (HYSD $\leq 1,024 \mathrm{~kg}$ ). These arbitrary limits contained 50 and $22 \%$ of all herd-year subclasses (38 and $32 \%$ of records) for low- and high-opportunity Mexican environments, respectively. The low-opportunity US environment contained 38\% of herd-year subclasses and $25 \%$ of all records.

\section{Model and Analysis}

Genetic parameters for first-lactation milk yield, $\mathrm{AFC}$, and CI within and between countries were estimated using a multivariate linear mixed sire model with unequal design matrices and missing observations. In matrix notation

$$
\mathrm{Y}=\mathrm{X} \beta+\mathrm{Wg}+\mathrm{Zu}+\mathrm{e}
$$

where $\mathbf{Y}=$ vector of record observations; $\mathbf{X}=$ incidence matrix for the herd-year-season contemporary group effects; $\beta$ = vector of unknown herd-year-season of calving group fixed effects; $\mathbf{Z}=$ incidence matrix for sire effects; $\mathbf{u}=$ vector of unknown random sire effects; $\mathbf{Q}=$ incidence matrix that relates sires to their respective genetic groups (15 genetic groups were defined based on sire's year of birth and origin); $\mathbf{W}=\mathbf{Z Q}$ because sires are nested within genetic groups; $\mathbf{g}=$ vector of unknown genetic-group fixed effects; and $\mathbf{e}=$ vector of residual effects.

The joint distribution of $\mathbf{u}$ and $\mathbf{e}$ was assumed to be multivariate normal with mean zero and variance

$$
\left[\begin{array}{l}
\mathbf{u} \\
\mathbf{e}
\end{array}\right] \sim \mathrm{N}\left[\left[\begin{array}{l}
\mathbf{0} \\
\mathbf{0}
\end{array}\right] \cdot\left[\begin{array}{ll}
\mathbf{G} & \mathbf{0} \\
\mathbf{0} & \mathbf{R}
\end{array}\right]\right.
$$

where $\mathbf{G}$ and $\mathbf{R}$ are the genetic and the residual (co)variance matrices, respectively.

\section{Estimation of Genetic Parameters}

Components of (Co)variance. Variance components for first-lactation milk yield, AFC, and CI within and between countries were estimated by considering performance in each opportunity environment as a separate trait. Variance components were estimated by simultaneously considering 3 or 4 traits at a time including at least 2 fertility traits. For example, the variance components in $\mathrm{G}$ were estimated by considering first-lactation milk yield in the average US herd (all US data) and AFC from the average Mexican herd (all Mexican data), and from low and high opportunity Mexican environments. Therefore,

$$
\begin{gathered}
\mathbf{G}=\text { variance }\left[\begin{array}{l}
\mathrm{u}_{1 \mathrm{ME} \text { U.S. all }} \\
\mathrm{u}_{2 \mathrm{AFC} \text { Mexico all }} \\
\mathrm{u}_{3 \text { AFC Mexico Low }} \\
\mathrm{u}_{4 \text { AFC Mexico High }}
\end{array}\right]= \\
{\left[\begin{array}{llll}
\mathbf{g}_{11} & \mathbf{g}_{12} & \mathbf{g}_{13} & \mathbf{g}_{14} \\
& \mathbf{g}_{\mathbf{2 2}} & \mathbf{0} & \mathbf{0} \\
& & \mathbf{g}_{33} & \mathbf{g}_{34} \\
\text { symm } & & & \mathbf{g}_{44}
\end{array}\right] \otimes \mathbf{A}=\mathbf{G}_{\mathbf{0}} \otimes \mathrm{A} .}
\end{gathered}
$$

where $\mathbf{G}_{\mathbf{0}}=$ genetic (co)variance matrix between sire effects $\left(\mathbf{u}_{i}\right)$ for the considered traits in different environments ( $1 / 4$ additive genetic variance). $\mathbf{A}=$ numerator relationship matrix among sires, and $\otimes$ is the Kronecker product. Residual covariances among records in different environments were assumed equal to zero. Genetic covariances between all data in Mexico and low and high opportunity environments within the same multivariate analysis were restricted to zero because $\mathrm{g}_{23}$ and $\mathrm{g}_{24}$ are subsets of $\mathrm{g}_{22}$. 
Estimates of (co)variance components and solutions for sire effects were obtained with REML methods (Boldman et al., 1995). The relationship matrix included sire of sire and maternal grandsire pathways. The initial values for sire and residual variance components were obtained from univariate solutions for traits analyzed for alternative opportunity environments. Convergence was assumed when the variance of the simplex values ( $-2 \log$ likelihood) was $<10^{-8}$. A global maximum was considered to be achieved when 3 restarts produced convergence without a change in the first 3 decimal places of the $F$ value (Boldman et al., 1995).

Genetic Correlation. Product-moment genetic correlation coefficients between opportunity environments $\mathrm{i}$ and $\mathrm{j}$ were estimated by

$$
\mathrm{r}_{\mathrm{g}(\mathrm{i}, \mathrm{j})}=\frac{\sigma_{\mathrm{ij}}}{\left(\sigma_{\mathrm{ii}} \sigma_{\mathrm{jj}}\right)^{0.5}}
$$

where $\sigma_{\mathrm{ij}}=$ genetic covariance between milk in the ith environment and fertility trait (AFC or CI) in the jth environment; $\sigma_{\mathrm{ii}}=$ genetic variance of milk in the ith environment, and $\sigma_{\mathrm{jj}}=$ genetic variance of a fertility trait in the jth environment.

Bivariate analyses provided estimates of the variance of the simplex value ( -2 log likelihood) for testing genetic correlation coefficients against zero using the likelihood ratio test (Robert et al., 1995). The maximum likelihood function was obtained for 2 models, one without constraint (full model) and a reduced model with genetic correlation set to zero. The difference in twice the log likelihood was used to test the result by $\chi^{2}$ statistic with 1 degree of freedom.

\section{Fertility Responses to Sire Selection for Milk}

Expected changes in AFC and CI were estimated by regressing the EBV for $\mathrm{AFC}$ and $\mathrm{CI}$ in Mexico and the US on the EBV for milk in the United States.

\section{RESULTS AND DISCUSSION}

\section{Genetic Parameter Estimates}

Phenotypic means for milk yield and AFC varied with mean HYSD in a manner consistent with our assumption of fewer inputs and less opportunity in low HYSD herds (Table 1). Preliminary analyses of relationships between milk and fertility within Mexico and the US (Table 2) indicated poorer fertility (longer CI) and younger cows at first calving with sire selection for milk. This genetic correlation coefficient agreed with findings by Ojango and Pollott (2001) for Holstein cows in Kenya $\left(r_{\mathrm{g}}=-0.20\right)$ and by Moore et al. (1991) in Canada $\left(r_{\mathrm{g}}=\right.$ $-0.29)$.

The estimated genetic correlation between milk yield in first lactation in an average Mexican herd and CI in the high opportunity environment was unfavorable $\left(\mathrm{r}_{\mathrm{g}}=\right.$ $0.10, P<0.0001)$. This antagonism may be smaller than in other studies: 0.67 (Pryce et al., 2002), 0.46 (HaileMariam et al., 2003), and 0.23 (Kadarmideen et al., 2003). The genetic correlations between milk yield in the average and low opportunity US environments and AFC in Mexican environments were also unfavorable (Table 2).

An important finding was that the genetic covariances between milk yield and AFC analyses within countries differed from analyses between countries: they were negative across Mexican environments (Table 2) but were positive between milk in US and AFC in Mexican herds (Table 3). This outcome implies inconsistent correlated responses to selection for milk between country production systems.

\section{Fertility Responses to Sire Selection}

Within-Country Information. The estimated daughter fertility responses across Mexican and US environments are in Table 2. Favorable responses in AFC were predicted when selection is based on milk yield within country with a decrease of 3 to $7 \mathrm{~d}$ per $1,000 \mathrm{~kg}$ of genetic gain in milk. Thus, predicted AFC responses were similar when selection is based on within-country milk yield information.

Unfavorable CI responses were predicted when selection is based on milk yield within country with a 3-d increase $/ 1,000 \mathrm{~kg}$ of genetic gain in milk in the average Mexican herd. In high-opportunity Mexican herds, CI may increase by $2 \mathrm{~d} / 1,000 \mathrm{~kg}$ of genetic gain in milk yield. Similarly, a CI increase of 1 to $2 \mathrm{~d} / 1,000 \mathrm{~kg}$ of genetic gain in milk may be expected in average- and low-opportunity US herds (Table 2).

Predicting Mexican Fertility Responses with US Information. Predicted genetic responses in fertility of Mexican cows to US germplasm are shown in Table 3. For the average Mexican herd, AFC is expected to increase by about $7 \mathrm{~d}$ and CI by about $2 \mathrm{~d} / 1,000 \mathrm{~kg}$ of genetic gain in first-lactation milk yield based on information from the average US herd. However, if selection were based on milking performance in low-opportunity US herds, a smaller AFC increase of about 4 $\mathrm{d} / 1,000 \mathrm{~kg}$ of genetic gain in milk yield may be expected in Mexican herds. Similarly, CI may increase by 1 to 2 $\mathrm{d} / 1,000 \mathrm{~kg}$ of genetic gain in milk yield.

This unequal AFC response to selection for milk production between countries may indicate genotype by environment interaction. Similar to milking ability, the 
Table 1. Number of records, means and standard deviations for first-lactation milk yield, age at first calving, calving interval, and herdyear standard deviation (HYSD) for milk in the US and Mexican data sets

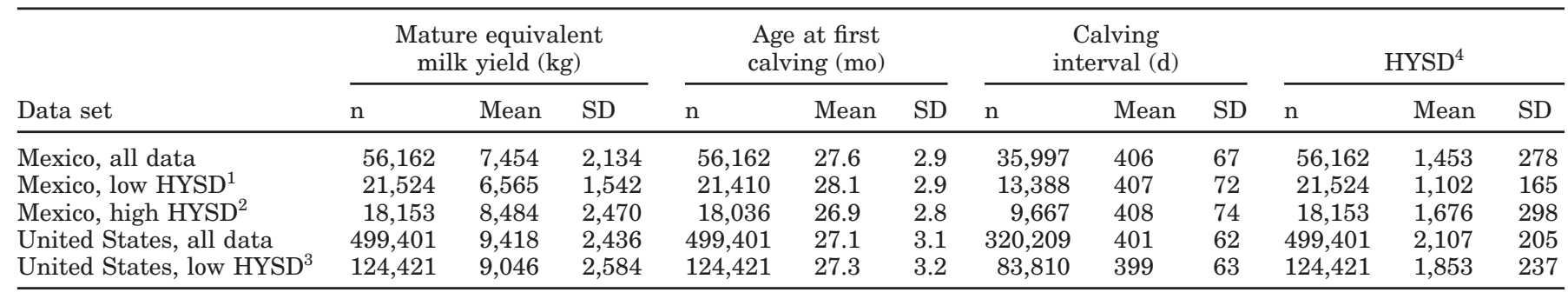

${ }^{1}$ Records from herds with HYSD $\leq 1,300 \mathrm{~kg}$.

${ }^{2}$ Records from herds with HYSD $\geq 1,600 \mathrm{~kg}$.

${ }^{3}$ Records from herds with HYSD $\leq 1,024 \mathrm{~kg}$.

${ }^{4}$ Average across herd-years.

increased age of Mexican cows at first calving may have resulted from their diminished growth expression compared with US half-sisters. These differences suggest a need for monitoring associations between these traits in Mexican production systems to facilitate genetic decision-making. Alternatively, these results could indicate differential breeding practices. Mexican farmers may have delayed breeding service for high-yielding daughters of high EBV sires to constrain semen cost by ensuring high pregnancy rates. Therefore, it will be important to disentangle the potential effect of age at first service of breeding females to accurately determine genetic improvement needs for alternative Mexican herds. Daughter pregnancy rate evaluations of US sires were not available when data for this study were obtained. A comparative assessment of daughter pregnancy rate across Mexican opportunity environments and the US should prove useful to dairy industries in Mexico and other Latin American countries.

\section{CONCLUSIONS}

Unequal genetic associations between milk yield and fertility traits were identified between opportunity environments in Mexico and the United States. The genetic association between milk yield and $\mathrm{AFC}$ was unfa-

Table 2. Within-country estimates of genetic $\left(r_{g}\right)$ and phenotypic $\left(r_{P}\right)$ correlation coefficients and predicted responses $\left(b_{\mathrm{XonY}}\right)$ from $1,000 \mathrm{~kg}$ of genetic gain in milk yield in first lactation for age at first calving (AFC) and calving interval (CI) across Mexican and US environments

\begin{tabular}{|c|c|c|c|c|c|c|}
\hline \multicolumn{2}{|c|}{ Data set } & \multirow[b]{2}{*}{$\operatorname{Var}_{\mathrm{g}}$} & \multirow[b]{2}{*}{$\mathrm{COV}_{\mathrm{g}}$} & \multirow[b]{2}{*}{$r_{g}$} & \multirow[b]{2}{*}{$r_{P}$} & \multirow[b]{2}{*}{$b_{\text {XonY }}$} \\
\hline Milk yield (X) & Fertility trait $(\mathrm{Y})$ & & & & & \\
\hline \multirow[t]{7}{*}{ Mexico, all data } & & 96,722 & & & & \\
\hline & Mexico, AFC all data & 273 & $-1,028$ & $-0.20^{\mathrm{a}}$ & -0.24 & -5.3 \\
\hline & Mexico, AFC low HYSD ${ }^{1}$ & 200 & -712 & $-0.16^{\mathrm{a}}$ & -0.10 & -3.6 \\
\hline & Mexico, AFC high HYSD ${ }^{2}$ & 358 & $-1,370$ & $-0.23^{\mathrm{a}}$ & -0.26 & -6.9 \\
\hline & Mexico, CI all data & 81 & 336 & $0.12^{\mathrm{a}}$ & 0.13 & 3.4 \\
\hline & Mexico, CI low HYSD & 25 & 31 & 0.02 & 0.02 & 3.0 \\
\hline & Mexico, CI high HYSD & 46 & 211 & $0.10^{\mathrm{a}}$ & 0.06 & 2.1 \\
\hline \multirow[t]{5}{*}{ United States, all data } & & 129,152 & & & & \\
\hline & United States, AFC all data & 415 & $-1,684$ & $-0.23^{\mathrm{a}}$ & -0.18 & -6.5 \\
\hline & United States, AFC low HYSD ${ }^{3}$ & 398 & -860 & $-0.12^{\mathrm{a}}$ & -0.11 & -3.3 \\
\hline & United States, CI all data & 95 & 420 & $0.12^{\mathrm{a}}$ & 0.14 & 1.6 \\
\hline & United States, CI low HYSD & 92 & 345 & $0.10^{\mathrm{a}}$ & 0.10 & 1.3 \\
\hline \multirow[t]{5}{*}{ United States, low HYSD } & & 124,732 & & & & \\
\hline & United States, AFC all data & & $-1,367$ & $-0.19^{\mathrm{a}}$ & -0.16 & -12.2 \\
\hline & United States, AFC low HYSD & & $-1,480$ & $-0.21^{\mathrm{a}}$ & -0.17 & -5.9 \\
\hline & United States, CI all data & & 310 & 0.09 & 0.05 & 1.2 \\
\hline & United States, CI low HYSD & & 373 & $0.11^{\mathrm{a}}$ & 0.06 & 1.4 \\
\hline
\end{tabular}

${ }^{\mathrm{a}}$ Genetic correlation coefficients different from zero $(P<0.001)$.

${ }^{1}$ Records from herds with herd-year standard deviation (HYSD) $\leq 1,300 \mathrm{~kg}$.

${ }^{2}$ Records from herds with HYSD $\geq 1,600 \mathrm{~kg}$.

${ }^{3}$ Records from herds with HYSD $\leq 1,024 \mathrm{~kg}$. 
Table 3. Estimates of genetic $\left(r_{g}\right)$ and phenotypic correlation coefficients $\left(r_{P}\right)$ between milk yield in first lactation in the average US herd (all data) and low herd-year standard deviation (HYSD) US herds and age at first calving (AFC), and calving interval (CI) in alternative Mexican herd environments

\begin{tabular}{|c|c|c|c|c|c|c|}
\hline \multicolumn{2}{|c|}{ Data set } & \multirow[b]{2}{*}{$\operatorname{Var}_{g}$} & \multirow[b]{2}{*}{$\mathrm{COV}_{\mathrm{g}}$} & \multirow[b]{2}{*}{$r_{g}$} & \multirow[b]{2}{*}{$\mathrm{r}_{\mathrm{P}}$} & \multirow[b]{2}{*}{$b_{\text {XonY }}$} \\
\hline Milk yield (x) & Fertility trait (y) & & & & & \\
\hline \multirow[t]{7}{*}{ United States, all data } & & 129,152 & & & & \\
\hline & Mexico, AFC all data & 273 & 1,069 & $0.18^{\mathrm{a}}$ & -0.10 & 7.2 \\
\hline & Mexico, AFC low HYSD ${ }^{1}$ & 200 & 254 & 0.05 & -0.04 & 1.9 \\
\hline & Mexico, AFC high HYSD ${ }^{2}$ & 358 & 680 & $0.10^{\mathrm{a}}$ & -0.10 & 5.2 \\
\hline & Mexico, CI all data & 81 & 323 & $0.10^{\mathrm{a}}$ & 0.08 & 2.4 \\
\hline & Mexico, CI low HYSD & 25 & 18 & 0.01 & 0.10 & 3.0 \\
\hline & Mexico, CI high HYSD & 46 & 146 & 0.06 & 0.10 & 1.1 \\
\hline \multirow[t]{7}{*}{ United States, low HYSD ${ }^{3}$} & & 124,732 & & & & \\
\hline & Mexico, AFC all data & 992 & $0.17^{\mathrm{a}}$ & -0.11 & 3.9 & \\
\hline & Mexico, AFC low HYSD & 150 & 0.03 & -0.09 & 0.6 & \\
\hline & Mexico, AFC high HYSD & 1,002 & $0.15^{\mathrm{a}}$ & -0.12 & 4.0 & \\
\hline & Mexico, CI all data & 286 & 0.09 & 0.10 & 2.2 & \\
\hline & Mexico, CI low HYSD & 18 & 0.01 & 0.05 & 0.08 & \\
\hline & Mexico, CI high HYSD & 216 & 0.09 & 0.12 & 1.1 & \\
\hline
\end{tabular}

${ }^{\text {a}}$ Exceeds zero $(P<0.001)$.

${ }^{1}$ Records from herds with HYSD $\leq 1,300 \mathrm{~kg}$.

${ }^{2}$ Records from herds with HYSD $\geq 1,600 \mathrm{~kg}$.

${ }^{3}$ Records from herds with HYSD $\leq 1,024 \mathrm{~kg}$.

vorable between milk in the United States and AFC in Mexican environments but favorable within Mexican herds. Differences in direction of this predicted fertility response might be evidence of genotype by environment interaction or differential breeding management. There is a need to disentangle the potential effect of age at first service of breeding females to evaluate genetic improvement needs for Mexican Holstein herds.

\section{REFERENCES}

Bagnato, A., and P. A. Oltenacu. 1993. Genetic study of fertility traits and production in different parities in Italian Friesian cattle. J. Anim. Breed. Genet. 110:126-134.

Blake, R. W., F. J. Holmann, J. Gutierrez, and G. F. Cevallos. 1988. Comparative profitability of United States Holstein artificial insemination sires in Mexico. J. Dairy Sci. 71:1378-1388.

Boldman, K. G., L. A. Kriese, L. D. Van Vleck, C. P. Van Tassell, and S. D. Kachman. 1995. A manual for use of MTDFREML. A set of programs to obtain estimates of variance and covariances. Draft. Revised. USDA-ARS, Roman L. Hruska U.S. Meat Animal Research Center, Clay Center, NE.

Bonczek, R. R., D. O. Richardson, E. D. Moore, R. H. Miller, J. R. Owen, H. H. Dowlen, and B. R. Bell. 1992. Correlated responses in reproduction accompanying selection for milk yield in Jerseys. J. Dairy Sci. 75:1154-1160.

Cabello, E., and R. Ruiz. 1998. Características de productividad de ganado Holstein Friesian en control de producción láctea. Técnica Pecuaria en México 39:38-43.

Castillo-Juarez, H., P. A. Oltenacu, R. W. Blake, C. E. McCulloch, and E. G. Cienfuegos-Rivas. 2000. Effect of herd environment on the genetic and phenotypic relationships among milk yield, conception rate, and somatic cell score in Holstein cattle. J. Dairy Sci. 83:807-814.

Cerón-Muñoz, M. F., H. Tonhati, C. N. Costa, J. Maldonado-Estrada, and D. Rojas-Sarmiento. 2004. Genotype $\times$ environment interaction for age at first calving in Brazilian and Colombian Holsteins. J. Dairy Sci. 87:2455-2458.

Cienfuegos-Rivas, E., P. A. Oltenacu, R. W. Blake, S. Schwager, H. Castillo-Juarez, and F. J. Ruiz. 1999. Interaction between milk yield for Holstein cows in Mexico and the United States. J. Dairy Sci. 82:2218-2223.

Costa, C. N., R. W. Blake, E. J. Pollak, P. A. Oltenacu, R. L. Quaas, and S. R. Searle. 2000. Genetic analysis of Holstein cattle populations in Brazil and the United States. J. Dairy Sci. 83:2963-2974.

Haile-Mariam, M., P. J. Bowman, and M. E. Goddard. 2003. Genetic and environmental relationship among calving interval, survival, persistency of milk yield and somatic cell count in dairy cattle. Livest. Prod. Sci. 80:189-200.

Hansen, L. B., A. E. Freeman, and P. J. Berger. 1983. Yield and fertility relationships in dairy cattle. J. Dairy Sci. 66:293-305.

Kadarmideen, H. N., R. Thompson, M. P. Coffey, and M. A. Kossaibati. 2003. Genetic parameters and evaluations from single- and multiple-trait analysis of dairy cow fertility and milk production. Livest. Prod. Sci. 81:183-195.

Marti, C. F., and D. A. Funk. 1994. Relationship between production and days open at different levels of herd production. J. Dairy Sci. 77:1682-1690.

Moore, R. K., P. P. Kennedy, L. R. Schaeffer, and J. E. Moxley. 1991. Relationships between age and body weight at calving and production in first-lactation Ayrshires and Holsteins. J. Dairy Sci. 74:269-278.

Nebel, R. L., and M. C. McGilliard. 1993. Interactions of high milk yield and reproductive performance in dairy cows. J. Dairy Sci. $76: 3257-3268$.

Ojango, J. M. K., and G. E. Pollott. 2001. Genetics of milk yield and fertility traits in Holstein-Friesian cattle on large-scale Kenyan farms. J. Anim. Sci. 79:1742-1750.

Pösö, J., and E. A. Möntysaari. 1996. Genetic relationships between reproductive disorders, operational days open and milk yield. Livest. Prod. Sci. 46:41-48.

Powell, R. L., and F. N. Dickinson. 1977. Progeny tests in the United States and in Mexico. J. Dairy Sci. 66:1768-1772.

Powell, R. L., and G. R. Wiggans. 1991. Animal model evaluations for Mexican Holsteins. J. Dairy Sci. 74:1420-1427.

Pryce, J. E., M. P. Coffey, S. H. Brotherstone, and J. A. Woolliams. 2002. Genetic relationships between calving interval and body condition score conditional on milk yield. J. Dairy Sci. 85:1590-1595.

Raffrenato, E., R. W. Blake, P. A. Oltenacu, J. Carvalheira, and G. Licitra. 2003. Genotype by environment interaction for yield and somatic cell score with alternative environmental definitions. J. Dairy Sci. 86:2470-2479. 
Robert, C., J. L. Foulley, and V. Ducrocq. 1995. Genetic variation of traits measured in several environments. I. Estimation and testing of homogeneous genetic and intra-class correlations between environments. Genet. Sel. Evol. 27:111-123.

Stanton, T. L., R. W. Blake, R. L. Quaas, and L. D. Van Vleck. 1991a. Response to selection of United States Holstein sires in Latin America. J. Dairy Sci. 74:651-664.
Stanton, T. L., R. W. Blake, R. L. Quaas, L. D. Van Vleck, and M. J. Carabaño. 1991b. Genotype by environment interaction for Holstein milk yield in Colombia, Mexico, and Puerto Rico. J. Dairy Sci. 74:1700-1714.

Windig, J. J., M. P. L. Calus, and R. F. Veerkamp. 2005. Influence of herd environment on health and fertility and their relationship with milk production. J. Dairy Sci. 88:335-347. 